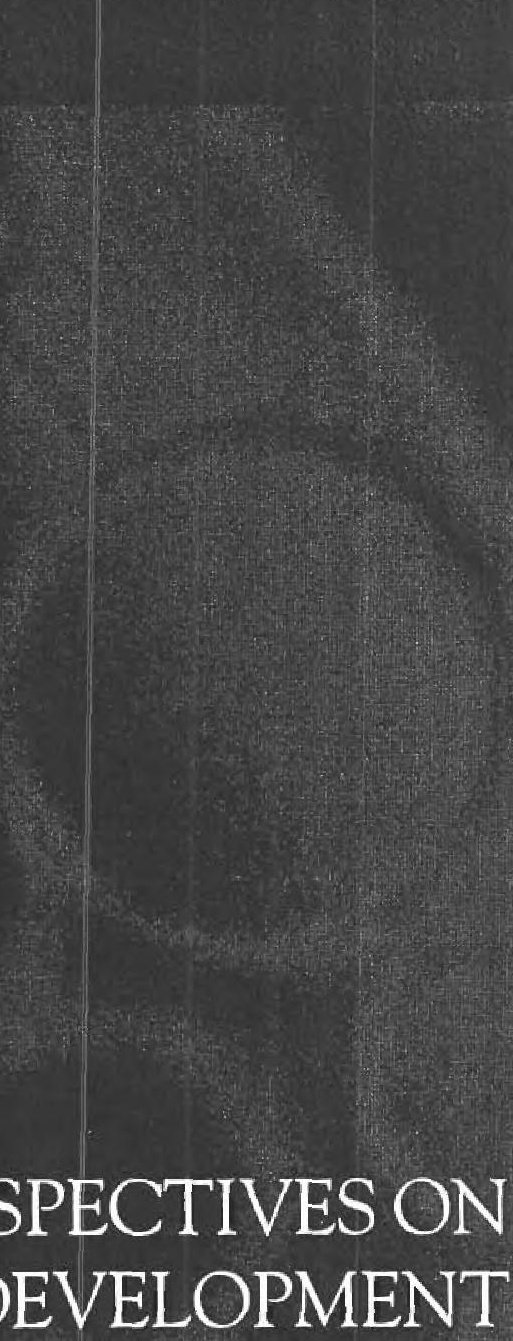

Anthony B. Atkinson, Kaushik Basu, Jagdish N. Bhagwati, Douglass C. North, Dani Rodrik, Frances Stewart, Joseph E. Stiglitz, Jeffrey G. Williamson

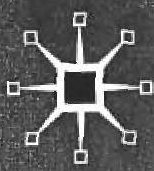




\title{
7 \\ Global Labour Standards and Local Freedoms
}

\author{
Kaushik Basu
}

\section{Introduction}

For some time I have been working on the problem of international labour standards, labour rights and child labour, and in particular the tensions between global intentions and local aspirations and freedoms. This gives rise to a host of practical problems concerning what the ILO should do, what the WTO could potentially do and what the global policy options are for the US government or the Finnish government. But I plan to dwell relatively little on these practical matters and spend more time on the abstruse theoretical questions that underlie this practical debate. I believe the theoretical debate is important to ensure that our interventions do not go wrong, do not hurt the very constituencies they are meant to help. The impatience that international bureaucrats and policy makers show with abst:act debates in their muscular desire to get on with the business of legislating and crafting policy can do much harm. And UNU-WIDER, perched uncomfortably between academe and the world of policy, is a good place to debate some of the abstract principles of economics that underlie global and national-level interventions to uphold minimal labour standards and worker rights.

In the city of Calcuitta, a large area called Salt Lake, which was originally a salt marsh, was developed by the local government, with the idea of enabling relatively worse off people to own land and houses. So plots were sold off at a subsidized rate. But it then struck the government that these people to whom the plots were sold could, in the future, lose their land to rich buyers offering to pay a lot more. So a law was enacted to disallow the sale of these Salt Lake plots to private buyers. The law was meant to help the disadvantaged people to whom the land was first sold. When I tell economists about this policy, they laugh. Surely, a person who wishes to sell their land will be better off by being able to sell it. So stopping a person from doing so can hardly be justified on the grounds of helping them. ${ }^{1}$

This is part of a larger principle in economics that virtually all economists are brought up on. A contract between two consenting adults, that has no 
negative fallout on an uninvolved third person, is their business. Government has no reason to intervene and stop such a contract - if anything, government should provide the machinery needed for enforcing such contracts. This 'principle of free contract' is, in turn, derived from a more fundamental axiom of normative economics, the Pareto principle, which asserts that any change which leaves one or more persons better off and no one worse off is a desirable change and ought not to be thwarted.

While most economists subscribe to the principle of free contract many, often unwittingly, support legislative interventions which seem to violate this principle. The same people who laugh at the folly of the government that enacted the Salt Lake legislation frequently support global conventions that disallow workers in poor countries from working at jobs that expose them to significant health hazards or from getting into bonded labour contracts with employers. A 'bonded labour' contract is one in which a worker receives an upfront payment (usually from a big landlord) and promises to pay it back by working for as long as necessary, often lasting several years and maybe even a lifetime, during which time he receives negligible wages (Genicot, 2002).

Banning these contracts is often justified by hand-waving references to the ubiquitous 'externality' that economists so often use as an alibi for intervention. I want to argue in this chapter that we need to be more circumspect in justifying bans on such market activity than we have been thus far. The world has gone through a phase of overvigilant government and overregulated markets within nations. This has given rise to the chorus of demand for economic reform and liberalization. What we are risking now is the same mistake at a global level.

Thanks to globalization, it is now easier to intervene in one another's nations and there is a genuine risk of overdoing this. I am not arguing against intervention per se. Governments and international organizations have important roles to play in controlling the market. But interventions have to be evaluated against some well-defined normative principles before they are put into effect. ${ }^{2}$ This is necessary to ensure that the agenda of global intervention is not hijacked by lobbies of northern protectionism, or elite interest groups in the south, and we do not end up with wanton interventionism.

The difficulty of the problem is best illustrated by John Stuart Mill's attempt to grapple with the issue of voluntary slavery. In his Principles of Political Economy (1848), after making a spirited case for the principle of free contract, Mill realized that it could take him into troubled waters. In particular, he was uneasy about the fact that some people, driven by their immediate poverty, might be willing to become slaves for life. This dilemma subsequently came to be known as the problem of 'voluntary slavery' or 'waranteeism' (Engerman, 1973). While slavery is usually rooted in an initial act of coercion (such as taking people prisoners by force), this is not necessary. There have been times when people, driven by poverty, would opt to become slaves. In the US state of Louisiana, for instance, Iegislation was passed in 1859 which allowed people the freedom to select masters and become slaves for life. ${ }^{3}$ Mill wanted to articulate a principle that would disallow waranteeism and so he argued that very long-term contracts, even if they were voluntary, should not be allowed. ${ }^{4}$ This does not seem like a compelling argument to me. It is too ad hoc. Besides, it could make it impossible to a get a thirty year mortgage for buying a house.

It is easy for all of us to agree that no worker should have to expose themself to excessive health hazards, and that no one should have to contract away their future labour so as to survive the day. But this does not mean that hazardous work should be banned and bonded labour contracts disallowed. Of course, no one should be poor enough to have to enter into these kinds of contracts. But if people are that poor, it is not evident that banning is the right response. There may,-nevertheless, be-a-case-for-some of-these bans but such a case has to be constructed much more carefully and checked against well-articulated principles, before they are put into effect. And we may also have, on occasion, to shelve the idea of a ban in favour of more nuanced policy interventions or even no policy intervention at all.

My aim here is to develop criteria against which potential interventions in the market will need to be checked, and to isolate conditions that must be fulfilled before we sanction the use of a legislative intervention in the market. But I want to begin by showing why wanton global intervention is especially risky in today's world.

\section{Globalization and the retreat of democracy}

One matter that has received little attention in the economics or the political science literature, and yet is important for understanding the tensions that can arise between global policy and local freedoms, is the intricate relation between globalization and democracy. ${ }^{5}$ This is an important precursor to the analysis of labour standards and so worth recounting, however briefly.

While much has been written in the economics literature on the benefits of globalization (see Bhagwati, 1995, 2004; and discussion in Basu, 2004), it is important to recognize that one concomitant of globalization is that, ceteris paribus, it tends to erode global democracy. This has either not been noticed or has been hushed up by those who did notice it in order not to sully the reputation of globalization. But globalization has many benefits to offer and we would be helping sustain it if we looked its negative fallout in the eye and worked to counter it, instead of glossing over it.

Democracy entails many things - the existence of a variety of political and legislative institutions, avenues for citizens to participate in the formation of economic policies that affect their lives and, in the ultimate analysis, a certain mindset. Yet at its core, democracy requires that people should have the right to choose those who rule them and who have influence over their lives 
and well-being, and the principle that the vote of one person should count as much as that of another persons.

Next, note that globalization, almost by definition, means that nations and people can exert a greater influence on other nations and the lives of citizens in other nations. Moreover, it is a fact that the power of one nation to influence another is by no means symmetric. The United States, for instance, can cut off the trade lines of Cuba. It can do so not only by curtailing its own trade with Cuba but by threatening punitive action against those who trade with or invest in Cuba. This is not just a hypothetical possibility, the US Helms-Burton Act is testimony to how it can actually happen. Cuba, on the other hand, can do little to hurt the American economy or polity. Likewise, China can do things to Taiwan, which Taiwan can in no way reciprocate and India to Nepal that Nepal would find hard to counter.

If we now bring the-'axioms' of the-two-previous paragraphs together, the 'proposition' is obvious: as the world shrinks and powerful governments clevelop a variety of instruments and ways to influence the lives of citizens in other nations, it is no longer enough for people to be able to choose the leaders of their own nations. Since democracy requires the ability to choose the leaders who have influence over your life, in a globalizing world such as today's citizens, especially those of poorer, weaker nations, need to be able to vote in the elections of the rich and powerful nations. Since such transnational voting does not happen (and even its hypothetical suggestion sounds absurd to us), globalization is bound to cause a diminution of global democracy. This is the 'dismal proposition' that I had tried to establish and warn against in Basu (2002a).

Fortunately or unfortunately, in today's world, to have influence in the affairs of another nation it is no longer necessary to occupy the other nation's land or even to go to war with it. There are, today, a variety of instruments that nations can use to influence outcomes elsewhere. Foremost among these is money. Thanks to the ease of instantaneous electronic links and the improving system of global guarantees, capital has flown across national boundaries as never before. And a rapid withdrawal of such capital can have devastating effects on the debtor nations, as we saw in 1997 when the Asian super-performing economies succumbed to financial crisis (Rakshit, 2002).

Like capital, international trade (after a slowdown in the years between the two world wars) has risen steadily. These global linkages have fuelled unprecedented growth rates of national incomes (during the 1990s, China grew at around 8 per cent per annum and India at 6.5 per cent) but they have also created new vulnerabilities. Governments and international organizations can now use the threat of disrupting these flows (or the lure of releasjng greater flows of money or goods) to enforce conformity to certain kinds of behaviour. And such threats have been used. International organizations have given money while insisting that the developing countries fulfil certain conditions, many of which have had nothing to do with ensuring repayment. These conditionalities have, at times, even been contradictory; such as requiring the debtor nation to practise democracy and for it to privatize certain key sectors, unmindfui of the fact that this was often against the collective wishes of the people.

Some of these conditions have been blatantly in the interest of the donor nation. In 1998, during the Asian crisis, the rescue package put together with money from several industrialized nations, most prominentily Japan and the United States, had clauses that required Korea to lift bans on imports of certain Japanese products (which Japan had for long been trying to sell to Korea) and to open up its banking sector to foreign banks (an item that had long been on America's bilateral agenda with Korea). ${ }^{6}$

Given that the benefits of democracy are ample, as modern research has shown, this erosion_of global democracy must have negative fallouts. Indeed, it is arguable that the rise in global unrest and political instabilities are a manifestation of this retreat of democracy. And the inchoate demands of the protestors in the streets of Seattle and Washington may be founded in an intuitive but ill-articulated perception of this erosion of democracy. This is a large and important problem, but not one that I am concerned with in this chapter.

Given that cross-country voting is unrealistic and not likely to happen, our best option is to strengthen global governance and make international organizations and global agreements sensitive to the needs of the poor in developing nations. Global conventions signed by ILO member countries, international,agreements on non-proliferation of arms, global treaties on the environment, the semblance of global law that is beginning to emerge as the WTO passes judgements on nations' trading practices and the International Criminal Court (ICC) established following the Rome Treaty of 1998, can all have a major role to play in influencing behaviour in distant lands and villages. ${ }^{7}$.The status of women in an African village and working conditions in a Vietnamese factory can be influenced by a global treaty on the rights of women and a global convention on labour. Hence, these global arrangements can have a major influence on global democracy and local freedoms. In crafting global conventions and agreements we have to keep in mind this larger role that they can and do play. It is with this awareness in the background that I want to enter the arena of global labour standards and local freedoms and well-being.

\section{Three examples of labour standards in developing countries}

Let us consider three rather controversial matters of international labour standards, where people are often tempted to intervene globally in local practices in developing countries. These are three of several possible contentious matters confronting international policy makers today. 


\section{Labour rights in export processing zones}

Many countries have done very well in the export market by creating special EPZs, where firms that produce, exclusively or primarily, for international markets are given special land and benefits by governments. Mexico's maquiladoras, China's special economic zones (SEZs), and Malaysia's numerous EPZs and 'licensed manufacturing warehouses', are examples of this. One of the things that multinationals working in these zones do not want is labour trouble and the disruption of work. To ensure this, some countries require workers in these zones to give up their collective bargaining rights and desist from trade union activity, and suspend the application of minimum wage laws (which are frequently the source of worker-management dispute), which may be effective elsewhere in the nation. That is, workers wanting to work in these zones have to relinquish some of the rights that other workers in other parts of the country can take-for-granted.

This has led to protests that EPZs that indulge in such practices are anti-labour and should be closed down. I do not think, however, that such a conclusion can be reached quite so easily. This is because no one is compelled to work in an EPZ. If a worker chooses to work in one and is accepted by a firm, then presumably both the worker and the employer like it that way and the principle of free contract seems to kick in. As Judge Robert Sweet, presiding over the case in which McDonald's was sued for causing obesity said, in dismissing the case, 'nobody is forced to eat at McDonald's'. 8

Moreover, investigations by the US Department of Labor (1990) confirm what most of us suspected - that, overall, workers in EPZs are better off than their counterparts elsewhere. It is true that in some countries workers in EPZs may have fewer rights, but typically they get higher pay and have superior working conditions. ${ }^{9}$ It is not surprising that many people would choose to work in an EPZ. Banning the practice of curtailing worker rights in EPZs is thus certainly not axiomatic, especially for the policy maker who values the Pareto criterion. There may be arguments for a ban but, to be compelling, such arguments need a great deal more sophistication than we have seen thus far. Moreover, we may need to distinguish between different kinds of cases.

The US Department of Labor (1990) study on EPZs reports a case in the Guangdong province of China, where some foreign-owned export firms were allegedly offered forced prison labour for work in the SEZs. The prisoners, mainly female prostitutes, would not be paid a salary but earn points towards their release, while the salary on their behalf would be collected by the Provincial Security Bureau. The firms reportedly rejected the offer so the scheme was not put into effect. But even if the firms had accepted it, such a contract quite obviously could not be defended under the principle of free contract. The fact that the workers in this case were being forced into this kind of work meant that the Pareto criterion would not apply here, ${ }^{10}$ and so we can rule this kind of practice in an EPZ as wrong without having to look for further justification. But a situation where workers have the option of not working in an EPZ, but nevertheless choose to work in one, is the context where one needs to have more sophisticated arguments for banning the EPZ, and also be prepared for the fact that there may not be such arguments. So we may have no good reason for interfering in the market in these developing nations. In a later section, I shall show how a case for intervention in some free-market transactions can be developed and how we may use it as a litmus test to decide which free-market agreements in labour markets can be construed as not permissible.

Lest it be thought that having special provisions for the export sector is a prerogative of Iess developed nations, let me emphasize that that is certainly not the case. The idea of export zones with special rights and privileges originated, in all likelihood, in Ireland and quickly took the form of an actual EPZ around Shannon airport in 1960. Moreover, the general phenomenon of having special laws for exporting firms has a long history in industrialized nations. In the United States, typically, there are very stiff anti-trust laws for firms indulging in collusive activity. However, there is another Iaw, the Webb-Pomerene Act of 1918, which exempts firms from the jurisdiction of anti-collusion law if they can show that the bulk of their production is for the export market. In Japan, firms have similar exemptions, and in fact an exporting, firm that breaks a cartel can actually be punished by government.

\section{Child Iabour}

A lot has been written about the reprehensible practice of child labour. But should it be banned? Should we stop the import of products that are made with child labour? I think the answers are not as obvious as may at first sight appear.

Before going into a discussion of these questions, let me briefly recount some of the facts. According to ILO (2002) estimates, there are currently 186 million child labourers in the world. ${ }^{11}$ Child labour is notoriously difficult to measure and any estimate can be subjected to criticism. The ILO estimate tends to overcount in some ways and undercount in some. It counts a child below the age of 12 as a labourer if the child reports having done paid work (or work towards producing a good that is sold on the market) for more than one hour in the previous reference period. ${ }^{12}$ What constitutes a 'reference period' can, however, vary - it can be a day or even a week. When it is a week, this amounts to a child doing 10 minutes or more work per day as being counted as a child labourer. This would seem to me to be too undemanding a condition: virtually every child in poor regions, if he or she reports truthfully, would be counted as a labourer. On the other hand, domestic work, some of which can be onerous and hazardous does not count as labour. This leads to serious undercounting of child labour and, especially, 'girl labour'. 
Not having any other statistics to hand and given that the above estimate is subject to both an overcount and an undercount, it seems reasonable at this stage to go along with the ILO estimates. It is evident that the incidence of child labour is very high and, in the twenty-first century with technology surging and human wealth reaching for the skies, this cannot but be a source of some embarrassment.

From this it is easy to jump to the conclusion that child labour should be banned. If, however, these children who work do so because they prefer to work and escape acute poverty then it is not obvious that there is a moral case for legislatively banning child labour. I shall show later that there may in some cases be a justification for a legislative ban (Basu and Van, 1998) but the argument is a complex one, resting on the possibility of multiple equilibria in the labour market, and whether or not this multiple equilibria argument applies-in-a-particular situation is ultimately an empirical matter. I shall return to this later.

As one might suspect, what policy stand we take on child labour depends crucially on what causes it, and the causes of child labour are many. In a region where schools are unavailable or of poor quality, the level of child labour is usually found to be high. ${ }^{13}$ In regions where schools provide incentives such as midday meals or other subsidies, there tends to be a lower level of child labour (Drèze and Kingdon, 1999; Ravallion and Wodon, 2000; Bourguignon, Ferreira, and Leite, 2003). Rural households that have more land often have their children working harder than households with no land (Bhalotra and Heady, 2003). However, the most compelling reason for child labour is undoubtedly poverty. If a household is sufficiently prosperous, it will not send its children to work, whether or not there is a school in the neighbourhood and whether or not it owns land. Barring rare exceptions, poverty seems a necessary condition for child labour, and there is now an enormous amount of micro and macro evidence on this. ${ }^{14}$

A single, elegant exercise that sums the situation up well is a figure that occurs is Humphries (2003), based on an earlier scatter diagram due to Krueger (1997: 281-302). The figure has GDP per capita on the horizontal axis and the percentage of children aged 10-14 years who work on the vertical axis. On this is plotted a point for each country in 1992. The scatter is a nicely declining one and a line fitted to this is a monotonically downwardsloping one, going from a child labour participation rate of nearly 50 per cent for very poor countries to nearly zero for countries with per capita-income above US $\$ 20,000$. In the same figure, Humphries inserts points representing the United Kingdom over time, in 1800, 1840 and 1870. During this period the United Kingdom was becoming richer, of course, and we find child labour falling. ${ }^{15}$ One can fit a virtual straight line through these points. Once again, we get a monotonically downward-sloping line, suggesting that as people become richer, child labour decreases. But the United Kingdom over time line is significantly above the cross-country line for 1992 . What does this tell us? That both lines are downward-sloping suggests that a greater income causes child labour to fall (in other words, poverty is a major cause of child labour) but the fact that in the nineteenth century child labour was greater than in 1992 for comparable per capita incomes reveals that income alone is not sufficient to explain child labour. It is possible that social norms matter (Basu, 1999; Lopez-Calva, 2003) and nineteenthcentury Britain had norms that tolerated more child labour. Or that technology matiers, and today's world has technology that discourages child labour (Humphries, 2003; Tuttle, 1999). One can think of many other factors.

However, if the primary reason for child labour is poverty, as seems to be the case, then the use of a legislative ban is harder to justify. One can say that no one should be poor enough to have to make their children work. But the fact is that many people are that poor. And then what? If we cannot obliterate poverty, should we tolerate child labour? The answer that I have given is that we should, in that case, try to improve adult wages and employment. This will on its own cause a lot of child labour to go away. But what happens if it turns out to be impossible to raise adult wage and employment? This is very possible in contexts where poverty itself is stubborn. Should we then legislatively ban child labour? My answer would be, typically, not even then. But the qualification, 'typically', is important because there are significant exceptions.

One possible exception, and therefore a case for a ban, would occur if we had evidence that children were being forced to work by their parents, guardians or whoever, because the use of force immediately puts such work outside the ambit of the principle of free contract. What constitutes forced labour in the context of children can be a philosophically tricky question (see Satz, 2003), since children are treated by us as not always able to judge their own interest. ${ }^{16}$ Children often have to be compelled to go to school by their parents - and the parents could be acting entirely in the interest of the children. Should schooling in such cases be described as 'forced schooling'? And even if the answer to that is 'yes', should we treat that as bad just because it is forced? It will be too much of a digression to go into these issues here, and it must suffice to have raised this problem and move on.

The other possible exception where legislative bans may be justified is the case where we may have reason to believe that there are multiple equilibria in the child labour market. I shall examine the importance of this argument later.

\section{Forced labour}

A topic where the difficulties of crafting global legislation is amply evident concerns forced labour. Stopping forced labour is part of the four core international labour standards that various global organizations have been campaigning for. ${ }^{17}$ But our understanding of 'forced labour' is predicated on our understanding of coercion and voluntariness. This is a topic on which 
economists have had very little to say, but there is a need to articulate the principles involved more clearly. In economics we make repeated reference to the free choice of agents, on how if people voluntarily choose something they must be better off with that thing, and so on. The principle of free contract mentioned at the start of this chapter makes critical use of the idea of voluntary choice and coercion. But economists have spent very little time on trying to understand what exactly these terms mean. Even in the world of policy making, these terms frequently crop up. We think poorly of forced labour. The ILO has begun work on counting the number of people who can be thought of as 'forced labourers' and enacting conventions to stop this practice - see ILO (2001) for a discussion. A commendable US law, the so-called Sanders' Amendment (1997), has ruled that the United States will not import products that are made using forced child labour.

But to have such policies work effectively and in the interest of the common person, we need to be clear about what the terms mean. Without that, there is a risk that these policies will be hijacked by those who have the best lawyers on their team, and the reference to force and voluntariness will become alibis for powerful lobbies to justify whatever it is that they wish to do. ${ }^{18}$ If we are to stop genuine forced labour and not just be an unwitting instrument of protectionism or partisan interest, we need to understand better what forced labour is.

Much of the early Chicago school writings erred on the side of voluntariness. As long as a person's decision is voluntary, most of us agree that the state should keep away. If we can claim that virtually all adult decisions are voluntary, then we can argue against government intervention virtually everywhere. And this fitted well with the Chicago school's market-fundamentalist predilection. Voluntary choice was often thought of by those belonging to this school of thought as equivalent to having choice, and being able to reject alternatives. But clearly, if one thinks it through a little, one realizes that this cannot be so. When one gives away one's watch to a mugger in response to the mugger having pulled out a gun and asked for the watch, one exercises choice. One did have the option of holding on to the watch and getting shot. But no one would think of a person parting with his watch at gun point as doing so voluntarily, unless one is under the sway of a completely tautological definition (Basu, 2000).

Likewise, many have erred on the side of 'force' - finding compulsion and force everywhere. If a worker accepts a low wage, it is because they are forced to do so. If a woman does not go to work, it must be because she is forced to stay at home. And if she does go to work, this is evidence that she is forced to go to work. To use these all-encompassing categories is to rob this important phenomenon of meaning and significance. If we are to stop coercion and force, we must move away from the traps of tautology on either side. I bring the example of forced labour here not to offer any answers but to impress on the reader that these problems of great legislative urgency can be matters of some analytical intricacy. Policy makers, impatient to get on with the task on hand, may not like to pause over such abstruse matters. But it is incumbent on us to think this, and other topics of labour legislation, through very carefully before we pass laws or plan interventions.

\section{When can we intervene?}

The topic of international labour standards belongs to the larger subject of the role of intervention in the functioning of markets. In particular, we are concerned here with global interventions in, typically, Third World markets. Should there be interventions and, if so, how should they be enforced? Should trade sanctions be used to punish a country that violates minimal labour standards? Naturally, this has been a very contentious subject ${ }^{19}$ and this is not the occasion for me to enter the fray. What I want to do here is simply outline three general principles against which a potential market intervention needs to be tested before it is put into effect.

\section{Irrationality and behavioural economics}

Human beings are often irrational. We are frequently impatient and willing to make disproportionate sacrifices to make good things happen soon. We lack self-control. We often count wrong, especially where returns over time are concerned. In particular, we are atrocious at understanding the implications of interest rates, where compounding is involved. In Indian villages I have noticed that the higher interest rates are usually quoted in per-month terms or per-week terms, whereas the lower interest rates are quoted in perannum terms. Though I have never put this to the test, my hunch is that stating it in terms of a month or a week allows the lender to camouflage the enormity of the interest rate. ${ }^{20}$ Modern behavioural economics has drawn the attention of economists to these systematic 'irrationalities' and opened a welcome chapter in economics. It is a bit dismaying, though, that economists needed behavioural economics to realize that people are not always rational.

The assumption of total rationality has played a major distorting role in our view of the role of government. One of the major achievements of modern society is that we do not have continuously to fear physical assault and the loss of our belongings and property. Most of the time when we go out for dinner we do so without having to fear that we will have to evict the people who may have moved into our homes during our absence. When we walk with a briefcase, we typically do not fear that it will be taken away by force. One reason for this great improvement on primitive life is that society recognizes the use of force and physical appropriation of another's belongings as wrong.

What, however, continues to happen nowadays is that people get duped out of their wealth. I am not using the word 'duped' here to mean obvious cheating, such as selling adulterated goods or defective products or misinforming 
the consumer. Against these, in principle, there is recourse. I am referring here to deals in which there is no cheating involved as such, and all information is put on the table. The duping here occurs in more subtle ways, by using the inability of agents fully to comprehend the information that is made available to them or the complications of the contract about to be signed, and also because of some common irrationalities. For instance, complex financial deals and sophisticated contracts, which are difficult for the common person to understand, make lots of people routinely lose out. The main reason society does not provide enough safeguards against this, in the same way that it prevents the physical appropriation of property, is the success of economists in persuading the policy maker that no one ever does get duped because human being are always rational.

When a villager regularly takes loans at the interest rate of 10 per cent or more per month, as I saw happen regularly during my field work in Jharkhand (see n. 20), economists explain this in terms of the alleged fact of a high default rate or monopoly pricing or fragmented credit markets. What we do not do is to allow for the fact that the borrower may not understand what ' 10 per cent per month' means in terms of the enormity of the repayment burden. Until recently, a paper that made such an assumption would be unlikely to get past the journal refereeing process. Fortunately, this is beginning to change now.

In reality, a failure to understand the meaning of interest rates is one of the major factors behind the prevalence of high rates in rural areas. I also believe that some of the poorest people are poor because of the lopsided deals they have made over the years. And it is possible that the people who become moneylenders in rural areas are ${ }_{r}$ maybe through a process of natural selection, individuals who are better at understanding the details of intertemporal deals.

The US Federal Trade Commission has brought to our attention the phenomenon of 'predatory lending'. This refers to the practice of (predatory) lenders locating an attractive property, typically with a single, elderly person living in it who, in their opinion, will be unable to pay back a large loan, and then offering them a large loan for home improvement at seemingly attractive terms. The aim here is to work into the contract exorbitant charges in the event of a default and even attempt to foreclose on the property when the person fails to pay back the loan. ${ }^{21}$ If borrowers assessed their ability to repay loans realistically, then there would be no scope for this phenomenon. Hence, the existence of predatory lending suggests a less than full rationality on the borrowers' part. Once this is recognized, there arises scope for legislative action that could not have been justified otherwise. Consider, for instance, hazardous work. If there is reason to believe that workers do not fully comprehend the long-run harm done to their health through certain kinds of hazardous work, then there could be a case for legally banning certain kinds of such work or fixing, legislatively, the amount of compensation that a worker who is involved in this kind of work must be paid. Presumably this will be an amount greater than what would occur naturally through the market, since the latter relies on the worker's perception of the hazard.

If we could show that parents do not understand the loss of human capital or damage to health that occurs in a child who works, then again this could be a reason to ban child labour. We must be careful, however, to recognize that it is not enough to show that a child's health is hurt through labour or that there is loss of human capital (even if this is huge). This argument is predicated on our being able to show that parents underestimate these costs of child labour, and that adults in hazardous work underestimate the long-run costs of such work.

The recognition of less than full rationality and the inability to calculate among ordinary people also opens the door for better redress for those who are tricked into accepting deals that hurt them. This is, however, a very difficult and risky area for government to get involved in, for it can easily lead to excessive intrusion in free-market decisions. Hence, this is a future policy option for us to keep in mind and discuss but not one on the basis of which I. would at this stage encourage interventions in labour markets.

\section{Multiple equilibria}

A general case where a Iegislative intervention in free-market contracts may be justified without having to disregard the Pareto principle is one where we have multiple equilibria. This idea has been used in several areas of development economics, from the theory of child labour to the analysis of policies for releasing a nation caught in the vicious circle of poverty. ${ }^{22}$ The idea is simplest to outline in a game-theoretic setting. Consider the problem of hazardous labour (though this could equally apply to child labour, or statutory limits on hours of work, or a worker's right to be part of a union). Let us consider a case where there are no government restrictions on hazardous work. Each worker looks around the labour market, at the wages that prevail for 'safe' work $(S)$ and 'hazardous' work $(H)$, and decides which to opt for. The worker, in other words, has a right to a safe environment but this is not an inalienable right. If he wishes to divest himself of this right in order to earn some more money (since, presumably, hazardous work will command a higher wage than safe work), he has the freedom to do so.

Now, without going into the details of the economy, it seems reasonable to posit that what a person wishes to do could depend on what others do, since what others do could affect the wages that hazardous work and safe work command. Improvising a bit on standard game-theory notation, let me denote by $B(H, H)$ the payoff that a worker gets if she does hazardous work and all other workers do hazardous work. The first $H$ in $B(H, H)$ denotes what the worker does and the second $H$ denotes what everybody else does. Likewise, I shall use $B(H, S)$ to denote the payoff that a worker expects to earn if she does hazardous work while everybody else does safe work. $B(S, H)$ and $B(S, S)$ are interpreted similarly. These are all net payoffs, and so take account 
of the pleasure of the income that such work brings and also the cost of leisure and hazard associated with this work. Let us now consider a case where the following assumptions are true

$$
B(H, H)>B(S, H)
$$

and

$$
B(S, S)>B(H, S)
$$

It is true that 1 have not specified the full game because it has not been stated what the payoff to an individual would be if half the remaining population does safe work and half does hazardous work, and so on. But even without going into this, it is evident that the assumptions of the payoffs just specified give rise to at least two Nash equilibria - one in which everybody chooses hazardous work and another in which no one does. For simplicity, let us assume that these are the only Nash equilibria of this game. Assumptions (7.1) and (7.2) in themselves do not tell us anything about the relative values of $B(H, H)$ and $B(S, S)$. Let us now assume that:

$$
B(S, S)>B(H, H)
$$

Now, let us consider an equilibrium in which everybody chooses to do hazardous work. Note that each individual, if asked separately what she prefers, hazardous work or safe work, will say 'hazardous' (this follows from (7.1)). Nevertheless, there is a case here for banning hazardous work. Such a ban would give rise to the outcome in which everybody does safe work. And since this is a Nash equilibrium, if people were now given the freedom to choose between safe and hazardous work, they would choose safe work. Moreover, by (7.3), they are all better off in this new equilibrium than the old one. Disallowing free contract, far from leading to a Pareto suboptimal outcome, has taken the economy to a Pareto superior outcome. Hence, if some economy has the characteristics just described, a legislative ban on hazardous work will be justified and, in fact, be required under the Pareto principle.

Another interesting possibility occurs if some people satisfy (7.3) but others satisfy the opposite inequality. Assume, for example, that there are two kinds of people in society: type $R$ and type $P$. We may think of $R$ as 'rich' and $P$ as 'poor'. Suppose now that everybody satisfies (7.1) and (7.2) but types $R$ and $P$ evaluate outcomes $(S, S)$ and $(H, H)$ differently. Assume, in particular, that:

$$
B_{P}(S, S)>B_{P}(H, H)
$$

and

$$
B_{R}(S, S)<B_{R}(H, H)
$$

In this economy, once again, there are two Nash equilibria - one where everybody chooses $S$ and another everybody chooses $H$. But neither of these two states Pareto dominates the other. Hence, if beginning from a state where everybody chooses $H$, the state bans $H$ (and so deflects society to the equilibrium where all choose $S$ ), this will not be a policy in violation of the Pareto principle. In the context of child labour (see Basu and Van, 1998; Basu, 1999) it can be shown, by constructing a full-fledged economic model, that multiple equilibria (namely, payoffs that have the above characteristics $)^{23}$ could well occur under realistic conditions. It will be interesting to attempt the same for hazardous work. ${ }^{24}$ Only after one has done so can one make a case for placing legislative restrictions on workplace hazard.

At times, we find some economists expressing scepticism about these kinds of multiple equilibria results, and the policies that arise from them, on the ground that we do not as yet have empirical evidence of there being multiple equilibria. This, however, is a fallacy because, just as we may not have evidence of multiple equilibria, we do not have hard evidence of the nonexistence of multiple equilibria either. Even if we observe an economy in one equilibrium, we cannot assume from this that the economy has a unique equilibrium. Hence, at least for the time being, the actual crafting of policy has to depend on the demonstration of theoretical possibilities and the marshalling of circumstantial empirical evidence, since empirically we have no reason for favouring one assumption over the other. ${ }^{25}$

1 want to end this section with two observations about law. Legal intervention in a multiple-equilibrium model is very different from what we see in standard models of law and economics. In the standard model, when a law is needed to change behaviour, one needs the persistent presence of the law. For instance, if you declare parking on a busy road illegal and subject to a fine, you will have to involve the law perennially there if you wish to prevent cars from being parked on that road. However, in the above model, once hazardous work has been banned for a while, even if the law is revoked, the economy does not return to the original situation, since the new outcome is an equilibrium in its own right. In Basu and Van (1998), we had called this a benign legal intervention. The advantage of economies with appropriate multiple equilibria is that we may not need perennial legal or government intervention. A benign intervention may be enough to 'cure' the problem once and for all.

The second point that it is important to keep in mind, especially in the context of this chapter, is that the efficacy of a nation's law depends critically on the extent of globalization. I have glossed over this in the model specified here, but in a more fully specified model, with globally mobile capital, the wage that workers in a nation can command will depend on the extent of capital attracted into the country.

The basic point is intuitively obvious. Consider a closed economy that bans hazardous work. This will have a certain effect on the wage rate 
that prevails for safe work, because presumably capital that supported firms involved in hazardous work will move over to non-hazardous work and likewise labour will move from one sector to another. Presumably, something ike this occurs behind the sparse-game model described above. Now suppose the same ban occurs in an open and globally integrated economy. It is entirely possible that capital will now shift not just to another sector but out of the country to another nation where there is no such law. And given that labour is not so mobile between nations, this will cause the 'safe' wage in this country (post-ban on hazardous work) to be lower than what it would be in a closed economy. Hence, a government concerned about labour welfare will find it harder to enact certain laws, effectively, in a more globalized environment. This is a theme that will be picked up later.

\section{The large numbers problem}

Let me finally turn to a theoretically more intricate route for justifying interventions to stop certain kinds of free-market contracts in the labour market. In economics, we often go from reasoning about a single contract or a limited number of contracts to taking a position on such contracts in general. As we have seen earlier, economists often argue that if a rational person wants to sell his house voluntarily and another rational person wants to buy it, then these two persons must be better off by the exchange, and since no one else has any obvious negative externality from this, it constitutes a Pareto improvement and so the state should not intervene. From this, they jump to the conclusion that the state should not stop individuals from selling their homes. An intervention that disallows such sales, they argue, is wrong.

This deductive jump is, however, not as innocuous as it may seem at first sight. Can we always go from arguing about the moral status of each single transaction to the moral status of a class of such transactions? This is a philosophically difficult question that economists tend to gloss over by answering or implicitly assuming the answer to be 'yes'. A serious investigation into this was undertaken by a philosopher. Derek Parfit, in his celebrated book on moral reasoning (Parfit, 1984), answers this question in the negative. That is, he argues that there are certain actions such that each one may be morally acceptable, but the totality of these actions may not be. ${ }^{26}$

At one level, Parfit's answer seems in easy accord with general-equilibrium theory, in particular, the concept of pecuniary externalities. Each single person signing an agreement to do hazardous work or to give up the right to join a trade union or the right to be protected against sexual harassment in the workplace may have no externalities since, by assumption, wages and prices are not affected by a single person's behaviour. So, a single person signing such a contract voluntarily must lead to a Pareto improvement (that person and his/her employer are better off and there is no effect on anybody else). But if lots of people sign such contracts, wages get affected and this could hurt the welfare of uninvolved individuals, thereby rendering the new outcome Pareto non-comparable to the old outcome.

Let me call this standard general-equilibrium (GE) proposition the 'GE reversal claim', or GERC. The paradoxical conclusion that GERC enables us to reach is this: if we are committed Paretians (and I maintain that we ought to be), then we should not object to individual workers agreeing to sign away their right not to be sexually harassed in the workplace, or their right not to expose themselves to large health hazards at work, or their right to collective bargaining in order to get some benefit in exchange - for instance, being able to work in an EPZ where work conditions may be particularly nice or simply to earn a higher wage. But we may nevertheless, without having to face the charge of inconsistency, enact a law that prohibits sexual harassment in the workplace or excessive health hazard at work or forbids everyone from giving up his/her right to bargain collectively, whether or not an individual worker and an employer find such a contract worthwhile. This is because the enactment of a law amounts to banning a whole class of actions or contracts, and we can, by GERC, take a different normative stand on a class of actions and on each action in the class.

It is interesting to note that the justification for this kind of a legislative ban is very different from the ones commonly proposed. Here, the case for the ban is founded on the harm it does to 'others' - those who suffer the pecuniary externalities of many people doing some kind of trade and exchange. ${ }^{27}$ Hence, if a firm offers job contracts which involve high wages but require workers to forgo the right not to be sexually harassed at work (and this is made clear to the worker at the time of her taking up employment), the reason why this should be stopped is not to protect individual workers from being harassed by this entrepreneur, but because of what firms offering such contracts do to wages and the well-being of workers - and, in particular, to the well-being of those who are especially strongly averse to harassment. This principle sounds inimical to our common sense, simply because we have reasoned so poorly for so long in these difficult areas of labour rights. But this is a very sensible way to understand why we may wish to legislate against EPZs where workers have to give up their rights or against contractual sexual harassment in the workplace, or against hazardous work.

The discerning reader will have noted that allowing workers the freedom to forgo a certain right does not lead to a Pareto improvement - does not mean that workers should not be allowed to forgo the right. All that we have shown is that, when the GERC principle holds we do not, on purely Paretian grounds, have a case for either upholding the right as inalienable or permitting workers to trade the right away. And, equivalently, upholding the right and not upholding it are both compatible with Paretianism. To go from this to a definite prescription, we need further moral axioms.

One route to such a further axiom is to note that we, quite naturally, think of certain human preferences as (morally) fine - or what will be here called 
'morally maintainable' - and others as not. A person's racist preference for giving jobs only to whites would be considered by most people as 'wrong' or not morally maintainable. On the other hand, we would consider a person's propensity not to work four days a week as fine - that is, morally maintainable. We would agree that this is likely to be harmful for the person themself, but not a preference that most of us would consider morally wrong.

Now among preferences that we consider morally maintainable, it seems possible to make some further distinctions. I have argued (Basu, 2003) that there are certain morally maintainable preferences, which are special in the sense that most of us would agree that not only do people have the right to have these preferences but, in addition, no one should have to pay a penalty for having such a preference. These may be called 'inviolable preferences'. Thus, while we agree that it is fine for Rip to want to sleep all day, four days a week, we at the same time see nothing wrong in the fact that Rip will have to pay the price of poverty for having this preference. On the other hand, most of us would agree that no one should have to pay a price for being averse to being sexually harassed or bullied. Hence, the preference not to be sexually harassed is an inviolable preference.

What exactly is considered an inviolable preference is of course not given a priori. Being a normative matter, there may also be disagreement between different societies about what should fall under the description of 'inviolable preference'. Is a father's aversion to letting his child do hard labour an inviolable preference or merely a morally maintainable preference? What about the preference not to be exposed to health hazards at work?

These could, of course, be contentious matters. ${ }^{28}$ But most of us would agree that there exist preferences that are inviolable. And this enables us to reach clear conclusions in choosing between certain Pareto non-comparable alternatives. Suppose states $x$ and $y$ are Pareto non-comparable but in $x$ some people who are especially averse to being sexually harassed have to pay a special price for having this preference. We should in that case consider $y$ superior.

The use of the GERC, along with the normative criterion of marking certain preferences as morally inviolable, could allow us to reach policy prescriptions about labour rights - in particular, to treat certain rights as inalienable.

It is worth noting that the moral criterion developed here belongs to neither welfarism nor deontological ethics. It involves a blending of welfarism and non-welfarist considerations. ${ }^{29}$ I shall call it here a 'miscible moral'. What I am arguing is that we should be welfarists in applying the Pareto criterion (that is, use individual welfare data to check if, between states $x$ and $y$, everybody is at least as well off in $x$ as in $y$ and there exists one person who is better off in $x$ than in $y$ and, if so, to declare $x$ to be socially superior to $y$ ) but among alternatives that are Pareto non-comparable we should be prepared go beyond people's welfare information. We should look at the basis of, or what underlies, a person's preference or welfare. If in state $x$, person $i$ is unable to go to the cinema and so $i$ prefers state $y$ to $x$, and in state $y$, person $j$ is exposed to large workplace health hazard or faces sexual harassment at work and so $j$ prefers $x$ to $y$, then in deciding between $x$ and $y$, society has to look beyond is and js welfare intensities. Society should choose $x$ because $y$ results in a violation of what we consider (to the extent that we do) to be someone's inviolable preference. The reason why this argument is partly welfarist is because it fully heeds the Pareto principle. But it is not entirely welfarist because non-welfare considerations kick in when the Pareto principle gives us no verdict. Observe that under this miscible moral system if an adult says that she hates to be harassed but is willing to put up with it (because of the higher wage promised by the sleazy employer), ${ }^{30}$ society has no authority to stop this transaction by saying that the harassment hurts her.

In the existing literature there is some discussion on unacceptable preferences, and this has led to the suggestion of using preference-based welfare criteria but only after the 'purification' of individual preferences (see Sen, 1997, for a discussion on this). It seems to me that such 'purification' should be allowed only in the event of Paretian non-comparability. Suppose a person gets pleasure (as an end in itself) from hurting others and suppose that this person plans to hurt another person. Should this be permitted? Or, more specifically, should this be allowed if the pleasure the 'hurter' gets is very large compared to the pain the 'hurtee' feels? ${ }^{31}$ My response will be: 'no, this should not be allowed, no matter how big the pleasure and how small the hurt' ${ }^{32}$ But now consider another case where the hurter offers to pay money to a free person in order to inflict pain on him and suppose the latter, after properly thinking it through, considers the offer acceptable. Should this transaction be allowed? Under the miscible moral system that I have proposed, the answer is 'yes'.

There is also an important theoretical agenda that this inquiry opens up, which I want to mention here only in passing. The possibility of there being transactions which by themselves are Pareto improving but in their collectivity may lead to a Pareto non-comparable or Pareto inferior state arises by the GERC. The claim is of course standard and is to be found in our textbooks. But that is no reason for accepting it. Is it really a reasonable principle? If each of a class of actions lead to a welfare increase, can all the actions together cause welfare to decline in any meaningful sense? The fact that this is assumed to happen in GE theory is no real consolation. Can such a theory be founded in a consistent logic? We know from the works of Aumann (1964) and Hildenbrand and Kirman (1988) that this is possible in a society with uncountably many individuals. I tried to show in Basu (1994) that in certain game-theoretic situations we can get such results with a countably infinite number of individuals. But evidently this is a topic that deserves further investigation. ${ }^{33}$ 


\section{Notes on international labour standards}

It is time to return to the mundane. Given the above problems and arguments, what is to be done? How can we have global labour standards that do not trample on local freedoms? This needs to be approached with an open mind. We should be prepared to do whatever is necessary, including doing nothing. The human mind has a natural propensity to prompt us, wherever we see a problem, to do something. In reality, there are lots of problems about which nothing can be done, or at least nothing can be done without making matters worse. The recognition that we live in a necessarily second-best world is important for realistic and successful policy making.

Some of the problems of labour standards are a concomitant of poverty. The only way to fight these is to fight poverty and we will be successful to the extent that we can be successful in mitigating global poverty.

Also worth keeping in mind is what mainstream economics keeps telling us - that much of what workers have achieved over the twentieth century has been achieved by virtue of the greater demand for labour and the consequent, automatic empowering of labourers. The power of what can be achieved by creating new legal rights may be small compared to what can be achieved by ensuring that labour demand keeps rising, which would enable workers on their own to ask for more and get it. This implies that trade channels ought to be left open. The use of trade sanctions to achieve certain ends should be discouraged. A direct implication of this is that labour standards should be in the charge of the ILO and not the WTO.

Further, the culture of contracts - whereby consenting adults can in general make agreements among themselves and have reasonable expectations that the agreements will be fulfilled because the state will help uphold such contracts or, more minimally, not negate them - can play an important role in improving living standards. The significance of this is routinely underestimated by policy makers.

Nevertheless and despite all the above caveats, as we have already seen there can be contexts where we may legitimately intervene in free-market contracts and exchange and do so without abandoning the Pareto axiom. The Pareto reversal proposition explains why we may want to legislate against certain classes of actions that may, on their own, seem to be Pareto improving. We have also seen that the existence of multiple equilibria provides a powerful case for banning certain voluntary, free-market exchanges. But all this applies to any legitimate governing authority. There is nothing special here about global interventions. But, interestingly, the multiple equilibria argument developed above can be taken further to provide a new justification for and give new meaning to the idea of international labour standards. As has already been pointed out in the discussion on hazardous work, in a world with globally mobile capital a ban on certain labour market practices may not succeed in deflecting the economy to the 'good equilibrium' the way it would have done in an economy where firms were country-specific. This is because every new, unilateral act of labour legislation would typically be expected to cause some flight of capital.

The only way to get around this is to have all countries - or, at least, all similarly placed countries - legislate simultaneously. This would limit the flight of capital associated with new legislation or government intervention. This is the principle reason why we need international labour standards as opposed to purely idiosyncratic and country-specific laws. But this also means that, when talking of international labour standards in poor countries, the initiative and the specific details of what goes into a package of international standards must come from developing countries and not from the governments or lobbies of industrialized nations, no matter how well-meaning they are.

I also hesitate about the use of consumer sanctions in industrialized countries to improve labour standards in poor nations. Moral monitoring through consumer activism runs the risk of playing into the hands of big businesses that have the power to direct opinion. Also, there is the genuine risk of witch-hunting - the criticism of some companies for violating labour codes that takes the form of hysteria and has very little actual basis. Given that labour standards in poor nations will be lower than in rich nations (not to allow for this is to hurt the poor nations), it is easy for people in industrialized nations to be misled into thinking that a firm that pays much lower wages in Vietnam compared to the United States is violating a moral standard.

Once the initiative gets passed onto poor countries and gives voice to workers and the dispossessed in those nations, we may end up getting a very different package of labour standards than the ones that are currently favoured. We may reach the conclusion that in very poor countries, such as Ethiopia and Nepal, where more than 40 per cent of children in the age group 10-14 years are labourers, child labour should not be banned, because this could cause deaths from starvation or drive children to other more dangerous livelihoods. We may reach the conclusion that employers must provide bathrooms for women close to the workplace because people close to the grassroots know that this is a major reason why women cannot take on certain kinds of jobs. It may be agreed upon that there should be no minimum wage laws in the poorest nations.

Giving voice to the Third World means risking that the agenda of international labour standards that we come up with will be significantly different from what would have emerged under the old order. But that is what global democracy is all about. 


\section{Notes}

The author thanks Tony Shorrocks for comments, and Alaka Basu, Gayatri Koolwal and Lorraine Telfer-Taivainen for editorial suggestions.

1. I have written about this Salt Lake phenomenon in Basu (2003).

2. This becomes especially important if we view development as essentially an expansion in the freedoms of the people concerned (Sen, 1999). Then, the curbing of free transactions in markets in the name of encouraging development has to be carefully crafted and justified so as not to be a self-contradictory policy.

3. It is interesting to note, however, that the Louisiana legislators were rather partial and granted this freedom only to persons of colour.

4. In later work Mill (1859) took a somewhat more sophisticated position on this, but never really managed to outline a compelling general principle for the exceptions.

5. I have discussed this at length in Basu (2002a).

6. The pressures on poor nations are not always in the deliberate self-interest of the donors and the industrialized nations. Many of the issues championed in various international fora are (as l discuss below) meant to be for the good of the poor nations. So my concern is not with the specific demands but with the mechanism through which these are brought to bear on the world. Once we create an effective mechanism, this can become a conduit for exploiting poor nations and bending them against their political will. The global mechanisms that are made available thus need to have built-in safeguards to prevent anti-democratic uses.

7. Shadow's were cast on this process when the US administration sought to withdraw from some major international treaties. On 6 May 2002, for instance, the US administration announced its intention to withdraw from the Rome Treaty and has actually worked to undermine the ICC by striking bilateral deals with nations to bypass the court, such as that signed with India on 26 December 2003.

8. See USAToday, 22 January 2003: www.usatoday.com/money/industries/food/ 2003-01-22-mcdonalds-lawsuit_x.htm.

9. See Kabeer (2000) for an excellent analysis in the context of Bangladeshi workers.

10. That is, the signing of this contract between the prison authority and a firm in the $\mathrm{EPZ}$ would not automatically lead to a Pareto improvement, since there is no reason to believe that the workers would be better off by this.

11. A 'child' for this purpose is someone below the age of 15 years.

12. For someone between the ages of 12 and 15 years, 14 hours or more work in the reference period has him/her classified as a child labourer.

13. For analyses of the relation between schooling and child labour, see Levison, Moe and Knaul (2001) and Rosati and Rossi (2003).

14. See, for instance, Krueger (1997), Ray (2000), Humphries (2003), Edmonds (2005). For surveys of some of this evidence, see Basu and Tzannatos (2003) and Brown, Deardorff and Stern (2003).

15. The claim is not without controversy, since child labour data, prior to 1951 , was very uneven in Britain. Humphries' (2003) numbers are based on her own computations.

16. Note that we typically speak about the rights of 'consenting adults' and not 'people'.

17. The other three being the stoppage of child labour, prevention of discrimination in the workplace and upholding of workers' rights to form unions and bargain collectively.
18. There is some evidence that this happening, as, for instance, when Sanders' Amendment was cited in the charge that was brought in the United States against Brazil's juice exporter, Sucocitrico Cutrale Ltd.

19. See, for example, Bhagwati $(1995,2004)$, Maskus (1997), Chau and Kanbur (2002), Kanbur (2003), Singh (2003), Winters (2003), Bhagwati $(1995,2004)$ and Satz (2004).

20. In the village of Nawadih, in the state of (now) Jharkhand, in eastern India, where I did four field trips in the early 1990s, I found that whenever interest rates crossed 100 per cent per annum, it would typically be stated in per month terms. Lots of poor farmers told me, for instance, that they had got loans from local landlords or money lenders at 10 per cent per month. I have my doubts if they realized that this amounted to an interest rate of over 200 per cent per annum.

21. 'Predatory lending' has been the subject of very good analysis by the US Federal Trade Commission. See, for instance, www.ftc.gov/os/2000/05/ predatorytestimony.htm.

22. See, for instance, Rosenstein-Rodan (1948); Nurkse (1953); Murphy, Shleifer and Vishny (1989); Matsuyama (1992); Basu and Van (1998); Hoff and Stiglitz (2001); Emerson and Souza (2002); Lopez-Calva (2003); Edmonds and Pavcnik (2005).

23. That model corresponds to the case described by (7.1), (7.2), (7.4) and (7.5).

24. If we build a competitive model with hazardous work and multiple equilibria, one important distinction will be that no equilibrium will Pareto dominate another equilibrium. This is because by the first fundamental theorem of welfare economics we know that each equilibrium must be Pareto optimal. However, our main claim would remain valid despite this. If, starting from an equilibrium where some workers do hazardous work, a ban is imposed on hazardous work and the economy moves to another equilibrium, we can be sure that this ban does not lead to a Pareto inferior outcome, since the new equilibrium must also be Pareto optimal.

25. In the context of child labour, we now know that both of these are available. In fact, the theoretical possibility of multiple equilibria occurs not only in models with exogenous law but even in models where child labour regulation is an endogenous choice of the citizenry (Doepke and Zilibotti, 2004).

26. See also Neeman (1999), Genicot (2002), Basu (2002b).

27. Needless to say, this is only for freely entered upon, contractual exchange. In coercive situations, one can appeal directly to the welfare loss of the aggrieved party.

28. This should not surprise us. We are trying to develop a normative policy principle. From Hume's law we know that we can never reach such a principle from propositions of pure facts and logic. When, on occasion, we feel we have done so, it must be that we have unwittingly slipped a normative axiom in to the discourse. All I am doing here is confronting the unavoidable normative axiom directly.

29. Welfarism has been critiqued effectively in the literature and in many different ways (see Sen, 1997, 2003). The critique being presented here is, however, different because it is based on rejecting welfarism only in the event of Paretian reticence.

30. The argument that she may be opting for this because of poverty is clearly no reason to stop the transaction. I would consider it a case for doing some thing to eradicate poverty so that no one has to make awful choices like this. But if someone is so poor as to wish to make this choice, clearly she would be even worse off if she were not allowed to do it.

31. I am grateful to Abhijit Baneriee for drawing my attention to this moral quandary. 
32. Note that in making this statement we have gone beyond welfarism, because if the same welfare profile were generated through another underlying story - for instance, the first person wanting to listen to music which the second person does not like - we might have reached a different prescription.

33. Following Parfit's (1984) lead I have, in Basu (2002b), explored some possibilities of such reversal results in finite societies, but this has to be viewed as no more than a beginning.

\section{References}

Aumann, R. (1964) 'Markets with a Continuum of Traders', Econometrica 32: 39-50.

Basu, K. (1994) 'Group Rationality, Utilitarianism and Escher's Waterfall', Games and Economic Behavior 7: 1-9.

(1999) 'Child Labor: Cause, Consequence and Cure with Remarks on International Labor Standards', Journal of Economic Literature 37: 1083-1119. (2000) Prelude to Political Economy: A Study of the Social and Political Foundations of Economics, Oxford: Oxford University Press. (2002a) 'The Retreat of Global Democracy', Indicators 1: 1-10.

(2002b) 'Sexual Harassment in the Workplace: An Economic Analysis with Implications for Worker Rights and Labor Standards Policy', Department of Economics Working Papers 02-11, Cambridge, MA: MIT.

(2003) 'The Economics and Law of Sexual Harassment in the Workplace', Joumal of Economic Perspectives 17: 141-57.

(2004) 'Globalization and Development: A Re-examination of Development Policy', in A. Kohsaka (ed.), New Development Strategies: Beyond the Washington Consensus, Basingstoke: Palgrave Macmillan.

Basu, K. and Z. Tzannatos (2003) 'The Global Child Labor Problem: What do we Know and What Can We Do?', World Bank Economic Review 17(2): 147-73.

Basu, K. and P. H. Van (1998) 'The Economics of Child Labor', American Economic Review 88(3): 412-27.

Bhagwati, J. (1995) 'Trade Liberalization and "Fair Trade" Demands: Addressing the EnvironmentaI and Labor Standards Issues', World Economy 18: 745-59. (2004). In Defense of Globalization, New York: Oxford University Press.

Bhalotra, S. and C. Heady (2003) 'Child Farm Labor: The Wealth Paradox', World Bank Economic Review 17(2): 197-228.

Bourguignon, F., F. H. G. Ferreira and P. G. Leite (2003) 'Conditional Cash Transfers, Schooling, and Child Labor: Microsimulating Brazil's Bolsa Escola Program', World Bank Economic Review 17(2): 229-54.

Brown, D., A. Deardorff and R. M. Stern (2003) 'Child Labour: Theory, Evidence and Policy', in K. Basu, H. Horn, L. Roman and J. Shapiro (eds), International Labour Standards, Malden, MA: Blackwell

Chau, N. and R. Kanbur (2002) 'The Adoption of International Labor Standards: Who, When, and Why', Brookings Trade Forum 2001, Washington, DC: Brookings Institution.

Doepke, M. and F. Zilibotti (2004) 'The Macroeconomics of Child Labor Regulation', Los Angeles: UCLA, mimeo.

Drèze, J. and G. Kingdon (1999) 'School Participation in Rural India', Development Economics Discussion Paper 18, London: LSE

Edmonds, E. (2005) 'Does Child Labor Decline with Improving Economic Status?', Joumal of Human Resources 40(1): 77-99.
Edmonds, E. and N. Pavcnik (2005) 'Child Labor in the GIobal Economy', Joumal of Economic Perspectives 19(1): 199-220.

Emerson, P. M. and A. P. Souza (2002) 'Is There a Child Labor Trap? lntergenerational Persistence of Child Labor in Brazil', Economic Development and Cultural Change 51(2): 375-98

Engerman, S. (1973) 'Some Considerations Relating to Property Rights in Man', Journal of Economic History 33: 43-65.

Genicot, G. (2002) 'Bonded Labor and Serfdom: A Paradox of Voluntary Choice', Journal of Development Economics 67(1): 101-27.

Hildenbrand, W. and A. Kirman (1988) Equilibrium Analysis, Amsterdam: North-Holland.

Hoff, K. and J. Stiglitz (2001) 'Modern Economic Theory and Development', in G. Meier and J. Stiglitz (eds), Frontiers of Development Economics, Oxford: Oxford University Press.

Humphries, J. (2003) 'The Parallels between the Past and the Present', in K. Basu, H. Horn, L. Roman and J. Shapiro (eds), Intermational Labour Standards, Malden, MA: Blackwell.

ILO (2001) Stopping Forced Labour, Geneva: ILO.

(2002) Every Child Counts: New Global Estimates on Child Labour, Geneva: ILO.

Kabeer, N. (2000) The Power to Choose: Bangladeshi Women and Labor Market Decisions in London and Dhaka, London: Verso.

Kanbur, R. (2003) 'On Obnoxious Markets', in P. K. Pattanaik and S. Cullenberg (eds), Globalization, Culture, and the Limits of the Market: Essays in Economics and Philosophy, New Delhi: Oxford University Press.

Krueger, A. (1997) 'International Labor Standards and Trade', Annual World Bank Conference on Development Economics 1996, Washington, DC: World Bank.

Levison, D., K. Moe and F. Knaul (2001) 'Youth Education and Work in Mexico', World Development 29: 167-88.

Lopez-Calva, L.-F. (2003) 'Social Norms, Coordination and Policy Issues in the Fight against Child Labour', in K. Basu, H. Horn, L. Roman and J. Shapiro (eds), International Labour Standards, Malden, MA: Blackwell.

Maskus, K. (1997) 'Should Core Labor Standards be Imposed through International Trade Policy', Washington, DC: International Trade Division, World Bank, mimeo.

Matsuyama, K. (1992) 'The Market Size, Entrepreneurship and the Big Push', Journal of Japanese and International Economics 6: 347-64.

Mill, J. S. (1848) Principles of Political Economy, 1970 edn, Harmondsworth: Penguin.

- (1859) On Liberty, London: Parker.

Murphy, K. M., A. Shleifer and R. Vishny (1989) 'Industrialization and the Big Push', Journal of Political Economy 97(5): 1003-26.

Neeman, Z. (1999) 'The Freedom to Contract and the Free-Rider Problem', Journal of Law, Economics and Organization 15(3): 685-703.

Nurkse, R. (1953) Problems of Capital Formation in Underdeveloped Countries, New York: Oxford University Press.

Parfit, D. (1984) Persons and Reasons, Oxford: Clarendon Press.

Rakshit, M. (2002) The East Asian Currency Crisis, New Delhi: Oxford University Press.

Ravallion, M. and Q. Wodon (2000) 'Does Child Labor Displace Schooling? Evidence on Behavioral Responses to an Enrollment Study', Economic Joumal 110: 158-76.

Ray, R. (2000) 'Analysis of Child Labor in Peru and Pakistan: A Comparative Study', Joumal of Population Economics 13(1): 3-19.

Rosati, F. C. and M. Rossi (2003) 'ChiIdren's Working Hours and School Enrollment: Evidence from Pakistan and Nicaragua', World Bank Economic Review 17: 283-96. 
Rosenstein-Rodan, P. N. (1948) 'Problems of Industrialization in Eastern and South Eastern Europe', Economic Joumal 53: 202-11.

Satz, D. (2003) 'Child Labor: A Normative Perspective', World Bank Economic Review 17: $297-310$.

(2004) 'Noxious Markets: Why Should Some Things Not Be for Sale?', in P. K. Pattanaik and S. Cullenberg (eds), Globalization, Culture, and the Limits of the Market: Essays in Economics and Philosophy, New Delhi: Oxford University Press.

Sen, A. (1997) 'Individual Preference as the Basis of Social Choice', in K. J. Arrow, A. Sen and K. Suzumura (eds), Social Choice Re-examined, London: Macmillan. (1999) Development as Freedom, New York: Alfred Knopf. (2003) 'Processes, Liberty and Rights', in A. Sen (ed.), Rationality and Freedom, Cambridge, MA: Harvard University Press.

Singh, N. (2003) 'The Theory of International Labour Standards', in K. Basu, H. Horn, L. Roman and J. Shapiro (eds), International Labour Standards, Malden, MA: Blackwell. Tuttle, C. (1999) Hard at Work in Factories and Mines: The Economics of Child Labor during the British Industrial Revolution, Boulder, CO: Westview Press.

US Department of Labor (1990) 'Worker Rights in Export Processing Zones', Foreign Labor Trends 90-32, Washington, DC: US Department of Labor.

Winters, L. A. (2003) 'Trade and Labour Standards: To Link or Not to Link?', in K. Basu, H. Horn, L. Roman and J. Shapiro (eds), International Labour Standards, MaIden, MA: Blackwell. 